\title{
Research on Dance Teaching Mode Based on Flipped Classroom in the Internet +Age
}

Fubo Ma

Art Academy, Northeast Agricultural University,China

E-mail:fuboma@126.com, http://www.neau.edu.cn

Chang Guo

College of Engineering, Northeast Agricultural University, China

E-mail:ceinuo@126.com, http://www.neau.edu.cn

Keywords: Internet, flipped classroom, dance teaching mode

Received: July 15, 2019

\begin{abstract}
The development of Internet technology has injected new impetus into the reform of education, and also posed new challenges to the traditional teaching mode. In recent years, as an extension of educational informationization, the flipped classroom has developed rapidly, and academic attention has increased year by year. At present, the flipped classroom in Colleges and universities in China has penetrated into many disciplines. Dance teaching should conform to the development of the times, optimize the teaching mode of dance education, open up innovative consciousness, and form a multi-channel teaching pattern. On the basis of discussing the theoretical and practical research on the mode of flipping classroom teaching in the dance teaching, this paper puts forward and designs the structure map of the pattern of the teaching mode of the flipped class in the ordinary university, and carries out a 4 month teaching experiment for the dance students. Through the analysis and verification of the data from the investigation and feedback, the conclusion is that the teaching mode of the dance flipping classroom has significant effect on improving the students' basic dance quality, dance performance and autonomous learning ability.
\end{abstract}

Povzetek: V prispevku je opisana uporaba umetne inteligence za izboljšanje učenja plesa.

\section{Introduction}

In twenty-first century, the rapid development of the information technology revolution and the continuous upgrading of the technology are slowly changing people's life, work and communication ways. It also brings opportunities for a series of changes in education and provides technical feasibility for the wide spread of classroom teaching. The current digital campus and the Internet of things have laid the material foundation for the flipping classroom. Mobile terminals provide technical tools for flipped classroom learning. At present, the advanced educational resources, such as micro video, Khan College and electronic desk, have provided convenient access to the implementation of the overturned classroom. With the continuous upgrade of technology, more and more information tools and methods will emerge to make learning easier and faster. To sum up, the development of modern information technology is the necessary condition for the smooth expansion of the flipped class, and the implementation of the information technology course cannot be separated from digital equipment. The development of technology has promoted the development of information technology courses and flip-flop classes, and the research on the teaching mode of junior dance based on flip-flop classes is essential. In the application of the overturned classroom teaching mode in the dance class in college sports, Zhang Qin (2016) concludes that the flipped classroom teaching mode is applied to the teaching of dance and dance courses in colleges and universities. It needs to be carried out in four aspects: the review of the content of video teaching before class + basic dance skills + effective autonomy and cooperation Learning + effective evaluation and careful ending design [1].

\section{The construction of dance teaching mode based on flipped classroom in the Internet age}

\subsection{The application of the flipped class in the Internet age}

From the implementation to the operation, the overturned class can be divided into four parts. The first is the preparatory stage of teaching, the second is the teaching memory and the understanding, the third is the implementation and the analysis stage, the last one is the comprehensive evaluation stage. The most important feature of this model is the reversal of roles. At the preparatory stage, the teacher is the protagonist, and in the understanding stage, the student becomes the protagonist in the classroom. At the stage of application analysis, students and teachers are both the protagonists. The last 
stage is mainly teachers scoring, which can be done by group [2].

\subsection{Design of dance teaching mode based on flipped classroom}

Because of the specialty of dance teaching, body movement is the expression form of the practitioner [3]. The practitioner needs to master the technical movements and practice a lot under the guidance of the teacher to form the dance skills. In the construction of the reversed classroom teaching mode in dance education, it is necessary to focus on the needs of students, so as to construct a more suitable dance education teaching mode in Colleges and universities. The structure diagram consists of three stages (Figure 1). They are pre-class preparation of classroom resources, in-class knowledge internalization and content upgrade, and after-class consolidation and improvement. According to the curriculum requirements of dance discipline, theoretical knowledge is understood and mastered. The process of the design of the structure drawing emphasizes the importance of communication. The process of communication and feedback is highlighted at the beginning of class. It breaks through innovation in the way of evaluation, and makes full use of teaching resources and communication platform. It highlights the advantages of the flipped classroom and combines the characteristics of dance education to provide reference for the reform of dance education [4].

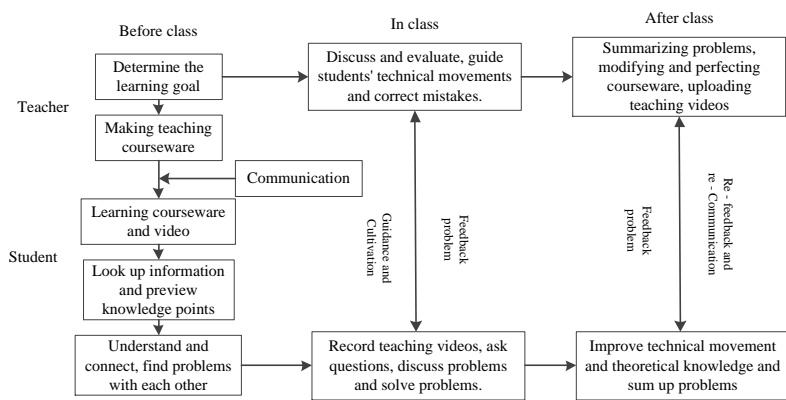

Figure 1: Structure of college dance teaching mode based on flipped classroom.

In the implementation steps of dance flipping classroom, it is designed in three stages (Figure 2).In the pre class stage, the teaching content should be cut in modules to set up the resources in various forms. It should be intuitionistic and effective. Students should conduct self-identification in the form of online testing or feedback. In this structure, the importance of feedback communication is emphasized, and new ideas are provided in the production of teaching content. The division of labor between teachers and students is clear and effective, and the design of teaching platform is more humanized. The way of online evaluation helps teachers and students to summarize and reflect, to further optimize the teaching plan and to support the students' learning and practice [5].

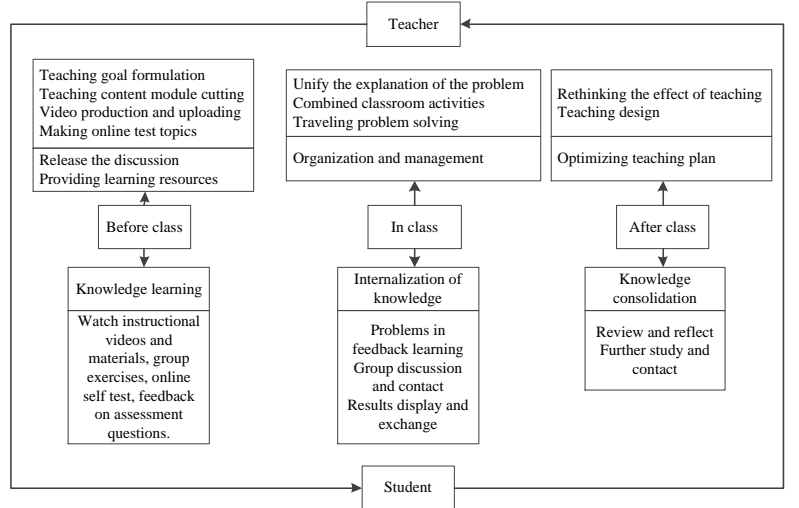

Figure 2: The steps of the dance flipping class.

The role of the teaching mode is mainly embodied in the teaching effect, which also reflects the current situation of teaching in China. The biggest feature of the flipping class is that it can improve the students' interest in learning and attract the attention of the students in class so as to improve their achievements and improve the teaching efficiency [6].

\section{Practice research of dance teaching based on flipped classroom}

\subsection{Research objects and methods}

In this paper, the application effect of flipped class in the teaching of dance in Colleges and universities is studied. A total of 120 students in the last semester of 2017-2018 year's dance courses were tested for a total of nine weeks of teaching experiments. The experimental class and the control class had a weekly class of 90 minutes each. The two classes consist mainly of two parts. One is the basic pace of dance, and the other is a small group of teachers. According to different teaching methods and reasonable arrangement order, the key points and difficulties are noted [7].

\begin{tabular}{|l|l|l|}
\hline $\begin{array}{l}\text { Evaluation } \\
\text { method }\end{array}$ & $\begin{array}{l}\text { Account for } \\
\text { the } \\
\text { proportion of } \\
\text { achievement } \\
\text { s }\end{array}$ & Evaluation subject \\
\hline $\begin{array}{l}\text { Attendance and } \\
\text { feedback video } \\
\text { frequency }\end{array}$ & $30 \%$ & Teacher evaluation \\
\hline $\begin{array}{l}\text { Classroom } \\
\text { participation } \\
\text { performance }\end{array}$ & $20 \%$ & $\begin{array}{l}\text { Teacher evaluation, } \\
\text { group evaluation, } \\
\text { self-evaluation }\end{array}$ \\
\hline $\begin{array}{l}\text { Group } \\
\text { presentation }\end{array}$ & $20 \%$ & $\begin{array}{l}\text { Teacher evaluation, } \\
\text { group evaluation, } \\
\text { self-evaluation }\end{array}$ \\
\hline
\end{tabular}

Table 1: Flipped classroom process evaluation.

As can be seen from the evaluation table, the main evaluation methods are the number of students in class and 
the number of feedback videos, classroom performance and group presentation. The number of classes and the frequency of feedback are evaluated by teachers. Class participation is mainly evaluated by students, groups and teachers.

\begin{tabular}{|c|c|c|}
\hline Grading project & Scoring index & $\begin{array}{l}\text { Scoring } \\
\text { body }\end{array}$ \\
\hline $\begin{array}{l}\text { Basic posture } \\
\text { (20 points) }\end{array}$ & $\begin{array}{l}\text { Stance ( } 5 \text { points) } \\
\text { grip ( } 5 \text { points) } \\
\text { back ( } 5 \text { points) } \\
\text { head ( } 5 \text { points) }\end{array}$ & \multirow{4}{*}{ Teacher } \\
\hline $\begin{array}{l}\text { Combined action } \\
\text { (40 points) }\end{array}$ & $\begin{array}{l}\text { Integrity (10 points) } \\
\text { fluency (10 points) } \\
\text { direction (10 points) } \\
\text { trajectory (10 points) }\end{array}$ & \\
\hline $\begin{array}{l}\text { Music performance } \\
\text { (30 points) }\end{array}$ & $\begin{array}{l}\text { Music rhythm } \\
\text { (30 points) }\end{array}$ & \\
\hline $\begin{array}{l}\text { Facial expression } \\
\text { and clothing } \\
\text { (10 points) }\end{array}$ & $\begin{array}{l}\text { Facial expression } \\
\text { ( } 5 \text { points) } \\
\text { Clothing ( } 5 \text { points) }\end{array}$ & \\
\hline
\end{tabular}

Table 2: Flipping class final skill test score.

The result of the evaluation is mainly the skill test at the end of the term, and the content of the examination is also the proportion of the score. It is mainly obtained by experts through questionnaires and data analysis. The main contents of the grading are basic posture, combined movements, music rhythm, facial expressions and clothing. The full score is one hundred points. The basic position is twenty points, while standing and holding posture and back and head are five points separately. The composition movement was forty points, the movement integrity, fluency, direction, track accounted for the ten points separately [8]. Musical rhythm has thirty points, facial expressions and clothing account for ten points. At the end of the final assessment, we invited three dance teachers from our school to carry out the score, which was carried out with a fair and strict attitude. The average score of three teachers are taken as the final result.

\subsection{Pre-test and post test data analysis}

\subsubsection{Pre-test results and analysis}

Before the experiment, the level of dance technology is measured. A basic step in dance is the main content of the test. At the same time, the basic situation of dance has also been investigated through questionnaires. In this way, we can get the cognition of the control class and experimental class to the dance.

According to table 3 , the students in the two classes have not been trained professionally. Only $3.3 \%$ of the students have been in contact with the dance before, and the other students have not been in contact with them. Therefore, the cognition of the two classes is zero. So the two classes have professional knowledge and technical mastery is relatively low, both classes are on the same starting line [9].

\begin{tabular}{|c|c|c|c|c|c|}
\hline & & \multicolumn{2}{|c|}{$\begin{array}{l}\text { Is there any } \\
\text { professional } \\
\text { training } \\
\text { before }\end{array}$} & \multicolumn{2}{|c|}{$\begin{array}{l}\text { Have you ever } \\
\text { been in } \\
\text { contact with a } \\
\text { dance before }\end{array}$} \\
\hline & & Yes & No & Yes & No \\
\hline \multirow{2}{*}{$\begin{array}{l}\text { Experi } \\
\text { mental } \\
\text { class }\end{array}$} & $\begin{array}{l}\text { Number of } \\
\text { people }\end{array}$ & 0 & 60 & 2 & 58 \\
\hline & Percentage & 0 & $100 \%$ & $3.3 \%$ & $96.7 \%$ \\
\hline \multirow[t]{2}{*}{$\begin{array}{l}\text { Control } \\
\text { class }\end{array}$} & $\begin{array}{l}\text { Number of } \\
\text { people }\end{array}$ & 0 & 60 & 2 & 58 \\
\hline & Percentage & 0 & $100 \%$ & $3.3 \%$ & $96.7 \%$ \\
\hline
\end{tabular}

Table 3: Investigation and statistics on basic situation of dance in experimental class and control class.

This article mainly takes the exercise attitude scale as the main weighing work. This table is mainly for young students, and there are eight main indicators. They are behavior attitude, behavior cognition, behavior habit, behavior intention, objective attitude, emotional experience, behavior control and subjective standard. Each index is formed by a different number of items. There are seventy entries, and the higher the score is, the better it is. In order to get a better understanding of the attitude of the two classes, the two classes were measured before the experiment, and the results of the measurements were found through table 4.

Through table 4 , we can learn that the two classes have more than $0.05 \mathrm{P}$ values in behavior attitude, target attitude, behavior cognition, habit, intention, emotional experience, behavior control and subjective standards. This shows that the two classes are not very different in these eight aspects. The exercises of the two classes are kept at the same level so as to meet the requirements of the experiment.

In order to get a detailed understanding of students' interest in dance lessons, a questionnaire survey was conducted before the experiment. According to the statistics, only $5 \%$ and $7 \%$ of the students in the two classes are very interested in learning dance, only $15 \%$ and $20 \%$ are interested. There are only $37 \%$ and $30 \%$ of the students with general interest. Those who were not interested accounted for $40 \%$ and $37 \%$, while those who did not like it accounted for $3 \%$ and $5 \%$ respectively. This also means that students are not interested in learning dance [10]. 


\begin{tabular}{|l|l|l|l|l|}
\hline & $\begin{array}{l}\text { Experimen } \\
\text { tal class } \\
(\mathrm{n}=60)\end{array}$ & $\begin{array}{l}\text { Control } \\
\text { class (n=60) }\end{array}$ & & \\
\hline $\mathrm{X} \pm \mathrm{S}$ & $\mathrm{X} \pm \mathrm{S}$ & $\begin{array}{l}\mathrm{t} \\
\text { value }\end{array}$ & $\begin{array}{l}\mathrm{P} \\
\text { value }\end{array}$ \\
\hline $\begin{array}{l}\text { Behavior } \\
\text { attitude }\end{array}$ & $28.36 \pm 6.59$ & $27.19 \pm 4.20$ & 0.914 & 0.361 \\
\hline $\begin{array}{l}\text { Objective } \\
\text { attitude }\end{array}$ & $40.01 \pm 7.36$ & $41.02 \pm 5.38$ & 0.775 & 0.436 \\
\hline $\begin{array}{l}\text { Behavior } \\
\text { cognition }\end{array}$ & $24.49 \pm 4.76$ & $25.48 \pm 5.08$ & 1.084 & 0.282 \\
\hline $\begin{array}{l}\text { Behavior } \\
\text { habits }\end{array}$ & $35.54 \pm 8.73$ & $33.59 \pm 5.91$ & 1.152 & 0.253 \\
\hline $\begin{array}{l}\text { Behaviora } \\
\text { I intention }\end{array}$ & $24.34 \pm 5.43$ & $25.51 \pm 5.34$ & 1.106 & 0.324 \\
\hline $\begin{array}{l}\text { Emotional } \\
\text { experienc } \\
\text { e }\end{array}$ & $33.35 \pm 6.32$ & $34.88 \pm 6.27$ & 1.102 & 0.264 \\
\hline $\begin{array}{l}\text { Behaviora } \\
\text { I control }\end{array}$ & $23.03 \pm 5.46$ & $21.47 \pm 4.52$ & 1.421 & 0.164 \\
\hline $\begin{array}{l}\text { Subjective } \\
\text { criteria }\end{array}$ & $20.45 \pm 5.38$ & $22.01 \pm 6.32$ & 1.153 & 0.253 \\
\hline
\end{tabular}

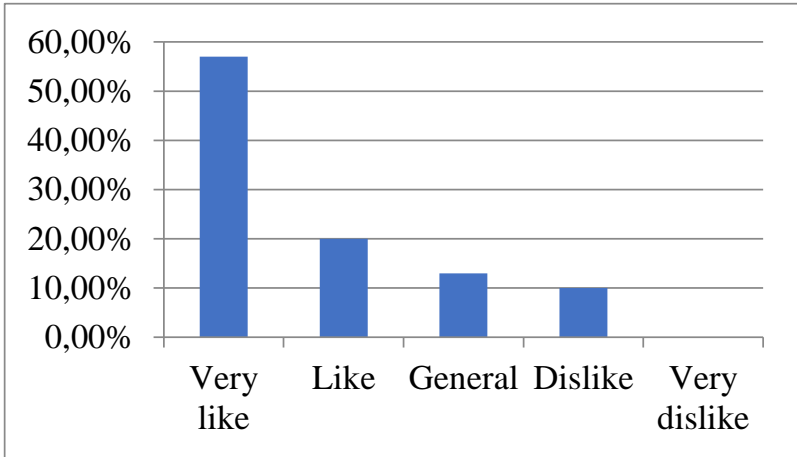

Figure 3: An analysis of the acceptance of the flipped classroom teaching.

According to figure 3 , it can be found that the person who likes it occupies $57 \%$, more than half of the people like it. People who like it occupy $20 \%$, and those who have the general interests have $13 \%$. There are $10 \%$ people who don't like it. The people who like to dance still occupy the vast majority. For the form of flip classroom teaching, students are still willing to accept it, especially the dance teaching under the flipped classroom [12].

First, a simple analysis of the results of the two classes is made from the basic positions, the movements of the combination, the rhythm of the music and the facial expression. According to table 5, we can learn that $\mathrm{a}=0.05$ is a basic test standard, while the students in the two classes have certain differences in the basic posture, the combination of the movements and the rhythm of the music, which also represents a certain effect in the flipped class at this time. The students in the two classes did not change in facial expression and clothing. According to

Table 4: Independent sample $\mathrm{T}$ test results of exercise attitude before and after test class.

In order to investigate the abilities of the two classes, a questionnaire survey was conducted before the experiment. According to the survey, it is found that the two classes have very little study before class, and most of them do not have to consolidate their study after class. Only a few students choose to listen to the teacher when they encounter something they don't understand in class. This also indicates that the students' learning situation is not very good.

\subsubsection{Post test results and analysis}

The degree of acceptance is mainly observed from the object being carried out, and whether the students can accept the dance class in the flipped class, mainly based on the degree of the students' preference. In order to get a clear understanding of students' acceptance, especially after the end of the experiment, a questionnaire survey was conducted among the students in the experimental class [11]. students in the two classes are quite different, and the $\mathrm{P}$ value is less than 0.05 . The result of the comparison between the two classes shows that the students in the experimental class are better than those in the control class.

During the period after the end of the teaching experiment, we conducted an independent sample $\mathrm{T}$ test on two classes (Table 7).

According to table 7, we can well observe the behavior attitude of the students in the experimental class and the control class, as well as the target attitude and the behavior habits. The six aspects of the $\mathrm{P}$ value are less than 0.05 , and this also represents the gap between the students of the two classes in these six aspects. The $\mathrm{P}$ value was higher than 0.05 in cognition and behavior control, which also showed that there was no significant difference between the two classes. 


\begin{tabular}{|l|l|l|l|}
\hline & $\begin{array}{l}\text { Experimental } \\
\text { class (score) }\end{array}$ & $\begin{array}{l}\text { Control class } \\
\text { (score) }\end{array}$ & P value \\
\hline & $\mathrm{X} \pm \mathrm{S}$ & $\mathrm{X} \pm \mathrm{S}$ & \\
\hline $\begin{array}{l}\text { Basic } \\
\text { attitude } \\
\text { achievement }\end{array}$ & $17.6 \pm 1.605$ & $15.01 \pm 2.492$ & 0.005 \\
\hline $\begin{array}{l}\text { Combined } \\
\text { action }\end{array}$ & $36.05 \pm 2.182$ & $32.98 \pm 3.267$ & 0003 \\
\hline $\begin{array}{l}\text { rhythm of } \\
\text { music }\end{array}$ & $30.02 \pm 1.237$ & $26.47 \pm 2.684$ & 0.004 \\
\hline $\begin{array}{l}\text { Facial } \\
\text { expression } \\
\text { and clothing }\end{array}$ & $9.41 \pm 0.482$ & $9.16 \pm 0.369$ & 0.250 \\
\hline
\end{tabular}

Table 5: Analysis of four indicators of technical performance in the experimental class and the control class

\begin{tabular}{|l|l|l|l|}
\hline & $\begin{array}{l}\text { Experimental } \\
\text { class (score) }\end{array}$ & $\begin{array}{l}\text { Control class } \\
\text { (score) }\end{array}$ & P value \\
\hline & $\mathrm{X} \pm \mathrm{S}$ & $\mathrm{X} \pm \mathrm{S}$ & \\
\hline $\begin{array}{l}\text { Technical } \\
\text { test results }\end{array}$ & $93 \pm 4.602$ & $86.42 \pm 6.387$ & 0.008 \\
\hline
\end{tabular}

Table 6: Total score analysis of final examination in experimental class and control class

After a period of learning, the dance learning in flipped classroom has achieved certain results. At the same time, there were questionnaires for students in the experimental class as well as in the control class. In the experimental class, about $60 \%$ of the students were interested in dance, and $19 \%$ of them had increased interest. Only $10 \%$ of them were only generally improved, and $5 \%$ still felt no interest. While $5 \%$ of the control class showed a significant improvement in their interest in dancing, 10\% showed a general improvement, and 79\% showed no change. Through these data, we can also know that flipped classroom has played a very positive role in enhancing students' learning [13].

\subsection{Implementation effect analysis}

Through the experimental data, we can see that the dance skills of the experimental class are higher than those of the control class. And the exercise attitude of the experimental class is better than the control class, and this also shows that the effect of the teaching in the flipped class has already achieved certain effect, so it is still very applicable in the University.

\begin{tabular}{|l|l|l|l|l|}
\hline & $\begin{array}{l}\text { Experiment } \\
\text { al class } \\
(n=60)\end{array}$ & $\begin{array}{l}\text { Control } \\
\text { class } \\
(n=60)\end{array}$ & & \\
\hline & $X \pm S$ & $X \pm S$ & $\begin{array}{l}\text { t } \\
\text { value }\end{array}$ & $\begin{array}{l}P \\
\text { value }\end{array}$ \\
\hline
\end{tabular}

\begin{tabular}{|l|l|l|l|l|}
\hline $\begin{array}{l}\text { Behavior } \\
\text { attitude }\end{array}$ & $26.01 \pm 5.08$ & $25.53 \pm 5.29$ & 1.326 & 0.043 \\
\hline $\begin{array}{l}\text { Objectiv } \\
\text { e } \\
\text { attitude }\end{array}$ & $44.89 \pm 5.98$ & $41.69 \pm 5.79$ & 2.302 & 0.026 \\
\hline $\begin{array}{l}\text { Behavior } \\
\text { cognition }\end{array}$ & $24.72 \pm 4.35$ & $26.01 \pm 5.31$ & 3.379 & 0.538 \\
\hline $\begin{array}{l}\text { Behavior } \\
\text { habits }\end{array}$ & $37.01 \pm 5.68$ & $33.29 \pm 5.36$ & 2.702 & 0.009 \\
\hline $\begin{array}{l}\text { Behavior } \\
\text { al } \\
\text { intention }\end{array}$ & $37.06 \pm 6.06$ & $33.06 \pm 8.32$ & 2.245 & 0.017 \\
\hline $\begin{array}{l}\text { Emotion } \\
\text { al } \\
\text { experien } \\
\text { ce }\end{array}$ & $25.58 \pm 6.70$ & $28.87 \pm 6.72$ & -2.226 & 0.011 \\
\hline $\begin{array}{l}\text { Behavior } \\
\text { al control }\end{array}$ & $22.98 \pm 5.51$ & $21.43 \pm 4.64$ & 1.412 & 0.164 \\
\hline $\begin{array}{l}\text { Subjectiv } \\
\text { e criteria }\end{array}$ & $25.25 \pm 5.23$ & $22.72 \pm 5.31$ & 2.134 & 0.034 \\
\hline
\end{tabular}

Table 7: Independent sample $\mathrm{T}$ test results of exercise attitude of experimental class and control class

Before class, teachers can make some micro-videos for teaching, which helps students consolidate their knowledge points after class. And students can do exercises repeatedly after class. In addition, students can learn in groups in the classroom, which is also conducive to improving students' learning ability [14].

The arrival of flipped classes makes students feel very fresh, which to a certain extent also increases students' interest in learning. The students' self-learning ability and cooperative learning ability are all exercised in all aspects. Their subjectivity has been brought into play, and the efficiency and quality of the teaching have been improved.

\section{Conclusion}

Based on the exploration and research of the new education model, the author recognizes that the new education mode in the overturning classroom is the trend of future development. The mode of flipping class extends the students' learning process to the class. The students get the information they need quickly through the network means. Compared with the traditional class, the flipping classroom teaching mode is more helpful to stimulate the students' interest in learning and mobilize the enthusiasm, initiative and creativity of the students' study. But this is not the only teaching mode. Because the educational situation in some places may not be appropriate, it cannot be implemented in a comprehensive way. Some developed areas can be decided according to the actual situation. For 
some areas with relatively backward economic conditions, careful consideration should be given.

\section{References}

[1] Smith S, Brown D, Purnell E, et al. 'Flipping' the Postgraduate Classroom: Supporting the Student Experience[M]// Global Innovation of Teaching and Learning in Higher Education. Springer International Publishing, 2015:295-315. https://doi.org/10.1007/978-3-319-10482-9_18

[2] Lin Y N, Hsia L H, Sung M Y, et al. Effects of integrating mobile technology-assisted peer assessment into flipped learning on students' dance skills and self-efficacy[J]. Interactive Learning Environments, (1), pp.1-16, 2018.

[3] Ting H H, Brito J P, Montori V M. Shared decision making: science and action[J]. Circulation Cardiovascular Quality \& Outcomes, 7(2), pp.323, 2014.

https://doi.org/10.1161/CIRCOUTCOMES.113.000 288

[4] Fevolden A M, Tømte C E. How Information and Communication Technology Is Shaping Higher Education[M]// The Palgrave International Handbook of Higher Education Policy and Governance. Palgrave Macmillan UK, 2015. https://doi.org/10.1007/978-1-137-45617-5_19

[5] Feng J Y, Li W Q. Practice and Research on Flipped Classroom Teaching based on MobileInternet[J]. Building Technology Development, 2017.

[6] Wen-Ying L U, Xian Peihua University. Research on Teacher-Student Interaction in Flipped Classroom Teaching Mode Based on MOOCs[J]. Journal of Tianjin Sino-German Vocational Technical College, 2016.

[7] Liu X. Research on "Flipped Classroom" Teaching Mode Based on Microlecture[J]. Shipbuilding Vocational Education, 2017.

[8] Fang F. Research on the Teaching Mode of Specialized Skills Courses Based on the Idea of Flipped Classroom:A Case Study of "Determination of Total Hardness of Water" in the School-based Textbook "Routine Detection"[J]. Science Education Article Collects, 2017.

[9] Zhang X, Computer S O. The teaching research of the dynamic website construction course based on the teaching mode of MOOC + flipped classroom teaching mode $[\mathrm{J}]$. Journal of Science of Teachers College \& University, 2017.

[10] Luo P, Xia-Fu L V, Min L I. The Research on Flipped Classroom Teaching Mode[J]. Education Teaching Forum, 2017.

[11] Liu J, Wang H. Research and Practice of the Teaching of Body Shaping Course Based on the Concept of Flipped Classroom[J]. Shanxi Science \& Technology, 2016.

[12] Zhao J, Guan M, Jiang L H. Research on Operations Teaching Mode Reform under Modular Teaching-Based on Flipped Classroom[J]Journal of Anhui Science \& Technology University, 2016.
[13] Siobhan B. Mitchell,Anne M. Haase,Sean P. Cumming,Robert M. Malina. Understanding growth and maturation in the context of ballet: a biocultural approach[J]. Research in Dance Education. 2017(3) https://doi.org/10.1080/14647893.2017.1387525

[14] Janet Withall,Anne M. Haase,Nicola E. Walsh,Anita Young,Fiona Cramp. Physical activity engagement in early rheumatoid arthritis: a qualitative study to inform intervention development[J]. Physiotherapy. 2016(3)

[15] https://doi.org/10.1016/j.physio.2015.07.002 